\title{
Supraglottic Cancer Pathologic Primary Tumor TNM Finding v8
}

National Cancer Institute

\section{Source}

National Cancer Institute. Supraglottic Cancer Pathologic Primary Tumor TNM Finding

v8. NCI Thesaurus. Code C133099.

A pathologic finding about one or more characteristics of supraglottic cancer, following the rules of the TNM AJCC V8 classification system as they pertain to stag ing of the primary tumor. 